\title{
Diagnosis and Evaluation of Fungi Presence in the Air of Two Different Ventilation Systems for Broiler Houses
}

- Author(s)
Gigli ACS 1
Baracho $\mathrm{MS}^{1,2}$
Nääs $\mathrm{A}^{1}$
Silva RA 1
Zago $\mathrm{R}^{1}$
Dall'Anese FP'
1 College of Agric. Eng. UNICAMP
2 College of Americana - FAM

\section{Mail Address}

Martin dos Santos Baracho
Unicamp - FEAGRI
P.O. Box 6011
13.081-970. Campinas, SP, Brazil
E-mail: martbaracho@yahoo.com.br

\section{Keywords}

Environment, fungi, poultry housing.

\section{Acknowledgements}

The authors would like to thank SAE/Unicamp for supporting the research.

\section{ABSTRACT}

Intensive broiler production in tropical climates requires adequate air circulation to control heat stress. Excess of air speed may lead to dust production and reduction of air quality and, consequently, production parameters. Brazilian regulations prohibit the presence of pathogens that may deteriorate air quality, and the presence of fungi in the air inside the poultry houses is limited to $750 \mathrm{CFU} / \mathrm{m}^{3}$. The aim of this study was to evaluate the presence of fungi in two distinct types of broiler houses. The research compared two types of air ventilation: conventional (G1) and positive tunnel ventilation (G2). The fungi were collected using a dust sampling pump, with the air flow calibrated to $1.5 \mathrm{~L} / \mathrm{min}$. The filter impregnated with dust was submitted to growth for two days using five Petri dishes. Microbiology analysis showed that there were 1,239 CFU and 2,011 CFU in G1 and G2, respectively. The different genera of fungi found and their percentages were: Penicillium 29.16\%, Aspergillus 37.5\% and Fusarium 29.16\% in G1 and Penicillium $33.34 \%$, Aspergillus 26.64\%, Fusarium 23.34\% and Neurospora 3.34\% in $\mathrm{G} 2$.

\section{INTRODUCTION}

Brazilian climate is tropical, generally warm and humid, which generates ideal conditions for the proliferation of toxigenic fungus, especially inside livestock housing. The great number of birds housed in high floor density leads to ideal conditions for the multiplication of microorganisms such as Aspergillus. This genus may develop into the living tissue of animals, particularly in the lungs, causing aspergillosis, a disease that can be found in several domestic or wild birds.

Broilers in intensive rearing systems are exposed continuously to concentrations of gases and suspended dust that would not occur in natural habitats. It is well known that such exposure has adverse effects on animal health and productivity, which have been described for poultry (Perkins \& Morrison, 1991; Kristensen \& Wathes, 2000). Besides, the environmental impact of aerial pollution provides another reason to minimize production of gases and dust (Wathes, 1998). In some production studies, the chronic exposure of domestic fowls to excessive dust and gases, such as ammonia, depressed feed intake and weight gain. The degree of response probably depends on the presence of concurrent respiratory diseases.

Fogging equipment and fans are often used In order to control excessive heat and relative humidity inside poultry houses. If on the one hand, these equipments may provide ideal thermoneutral environmental conditions inside the houses, on the other hand, they may increase air speed and generate large amounts of suspended particles. 
Procedures that prevent fungal contamination and growth should be taken. Among these, the input of products with good quality is essential, mainly regarding feed processing and storage.

According to Quilles \& Hevia (2003), the lack of a security plan results in great risk to the agricultural production, because security is a basic aspect to reduce the incidence of many avian diseases. The concept of safety refers to the maintenance of an environment free of microorganisms or yet with a minimum load that may not interfere in the production (Quilles \& Hevia, 2003). Measures of environment safety are designed to prevent the introduction of pathogens that may affect the health, welfare and thermal conditions of the birds.

Fungi occur worldwide and are found in various feedstuffs, including roughages and concentrates. Under specific ambient conditions, fungi produce substances called mycotoxins. These may be produced in the field, prior to harvest, or post-harvest, during storage, processing, or yet feeding. Mold growth and the occurrence of mycotoxins are often related to extreme weather conditions, which can cause plant stress or feedstuff moistening; to poor storage practices, which affect feedstuff quality; and to conditions of feed distribution.

Aflatoxins are produced in nature only by species $A$. flavus and $A$. parasiticus. The four major naturally produced aflatoxins are known as aflatoxins B1, B2, G1 and G2 (Leeson et al., 1995). Aflatoxins are both acutely and chronically toxic to animals and man. They may induce acute liver damage, liver cirrhosis and tumors, or may have teratogenic effects (Stoloff, 1983). Aspergillus fumigatus is a fungus responsible for pulmonary infections (Fraser, 1993; Daly \& Kavanagh, 2001). In this form of the disease, Aspergillus invades the lung walls and causes necrosis, spreading throughout the body (Daly \& Kavanagh, 2001).

The objective of this study was to evaluate the air quality in two broiler houses with distinct ventilation systems under tropical conditions.

\section{MATERIAL AND METHODS}

The trial was carried out at longitude $47^{\circ} 37^{\prime} 52^{\prime \prime}$ W and latitude $22^{\circ} 24^{\prime} 54^{\prime \prime} \mathrm{S}$, in Rio Claro, São Paulo State, Brazil. One-day-old Avian ${ }^{\circledR}$ genetic chicks $(n=44,100)$ were distributed into two poultry houses with East-West solar orientation and measuring $115 \mathrm{~m}$ long, $12 \mathrm{~m}$ wide and $3.2 \mathrm{~m}$ average height (center: $3.6 \mathrm{~m}$, eaves: $2.8 \mathrm{~m}$ ). White-painted fiber cement tile roofing was used. Wood shavings were used as bedding material and the side walls were of blue plastic curtains. In the first poultry house (G1) there were six fans (1 HP placed at $1.20 \mathrm{~m}$ from the floor) facing the West side to follow the pattern of natural wind flow. There were also two fogging lines. The second house (G2) was an adapted tunnel ventilation system. Positive and negative pressures were combined using eight axial positive pressure fans $(0.5 \mathrm{HP}$ placed at $1.20 \mathrm{~m}$ from the floor), four negative pressure fans (1.5 HP fixed $0.60 \mathrm{~m}$ from the floor) on the East wall to remove the air from inside, and five axial fans $(0.5 \mathrm{HP}$ fixed $0.60 \mathrm{~m}$ from the floor) on the West wall to push the incoming air inside the house. Two lines of fogging were used inside, and the building was tightly closed with additional PVC blue curtains to allow adequate work of the negative pressure. The two houses were considered two treatments, i.e., G1 was the natural housing system, with natural ventilation, heating in the first three weeks of age, and stocking density of $13 \mathrm{birds} / \mathrm{m}^{2}$; and $\mathrm{G} 2$ was the positive tunnel ventilation system ( 5 inlet fans, 4 outlet exhaust fans and 8 intermediate fans), with stocking density of 18 birds/ $\mathrm{m}^{2}$ and heating provided in the first three weeks. The side walls were closed with curtains. During the heating period, natural systems of curtain openings were equally adopted for both houses. The birds were randomly distributed in both treatments. Each house was divided into three parts using a wired net in order to avoid movement between the sectors. A datalogger was placed externally and at the geometric center of each sector for continuous measurement of dry bulb temperature and wet bulb temperature. Sampling of fungi was performed using a dust sampling pump (Gilian Instrument model GilAir-5), adjusted to an air flow of $1.5 \mathrm{~L} / \mathrm{mi}$, for 15 minutes during the mornings from 22 October to 03 December of 2003, for five weeks (birds aged 7 days, 14 days, 21 days, 28 days and 35 days). After impaction of the dust, the filter was submitted to microbiological analysis. Growth was allowed for two days in five Petri dish and the colonies were transferred to other dishes, and finally streaked onto fresh Petri dishes in order to obtain pure cultures. Each colony was classified according to the morphology (Raper \& Fennel, 1965; Silveira, 1968) and the number of colony forming units (CFU) was determined. Simple analysis of correlation was used to estimate the relation between temperature, humidity and CFU. The linear correlation was defined using the Pearson correlation test. 


\section{RESULTS AND DISCUSSION}

Table 1 shows the percentage of each fungus genus identified in the two treatments. Aspergillus was the most common genus in both treatments. Positive tunnel ventilation (G2) had generally higher values except for Aspergillus (26.67\%) and Fusarium (23.33\%). This finding is probably a result of the higher animal density used in the positive ventilation and to the more tightly closed house, conditions that promote microorganism multiplication.

\begin{tabular}{|c|c|c|}
\hline Genus & G1 (\%) & G2 (\%) \\
\hline Penicillium & 29.16 & 33.34 \\
\hline Aspergillus & 37.50 & 26.67 \\
\hline Fusarium & 29.16 & 23.33 \\
\hline Neurospora & 0 & 3.33 \\
\hline Not identified & 4.18 & 13.33 \\
\hline
\end{tabular}

Analysis of the data showed Aspergillus growth in both treatments, suggesting that a more effective control is needed. Since Fraser (1993) and Daly \& Kavanagh (2001) reported that Aspergillus in poultry houses are responsible for pulmonary infections, the data found here may indicate that illnesses might occur, as aspergillosis that it was reported too by Fraser (1991); El-Gharib et al. (1993); Cervantes (1995); Vilar et al. (1995); Richard (1977), in young animals as one of the main illnesses in commercial production of birds. In aspergillosis, fungus may be found in the air sacks and the lungs, resulting in embryo and chick mortality. In saturation conditions, the genera found in work environments (Penicillium and Aspergillus) may cause allergies and even serious pulmonary illnesses in workers (Todaro, 1978; Strom \& Blomquist, 1986). They are significantly important due to dissemination of the diseases caused by them.

Table 2 shows that the temperature in five weeks (35 days) varied from 22.03 to $27.33^{\circ} \mathrm{C}$ and mean relative humidity varied from 51 to $81.93 \%$. These conditions are ideal for fungus growth.

The statistical analysis that correlated relative humidity, temperature and fungus CFU (Colony Forming Units) in air suspension was not significant for both $G 1$ (1.239) and $G 2$ (2.011) $(p<0.31$ and $p<0.52$, respectively) indicating that the use of higher air speed inside the poultry house does not necessarily lead to lower air quality.

\begin{tabular}{|c|c|c|c|c|}
\hline \multirow{2}{*}{$\begin{array}{l}\text { Age } \\
\text { (d) }\end{array}$} & \multicolumn{2}{|r|}{ G1 } & \multicolumn{2}{|r|}{ G2 } \\
\hline & RH (\%) & Temperature $\left({ }^{\circ} \mathrm{C}\right)$ & RH (\%) & Temperature $\left({ }^{\circ} \mathrm{C}\right)$ \\
\hline 7 & 71.97 & 22.82 & 73.34 & 22.03 \\
\hline 14 & 58.41 & 27.27 & 56.52 & 27.33 \\
\hline 21 & 77.57 & 24.17 & 51.57 & 24.38 \\
\hline 28 & 80.06 & 23.65 & 77.84 & 24.00 \\
\hline 35 & 81.93 & 24.99 & 80.46 & 25.92 \\
\hline
\end{tabular}

\section{CONCLUSION}

The fungus genera isolated from the airflow in the present study are toxicogenic. In regard to the presence of pathogenic and toxinogenic fungus in the air, Resolution 176-DOU (Resolução 176-DOU, Brasil, 2000) defines the maximum acceptable level of fungus as $750 \mathrm{CFU} / \mathrm{m}^{3}$. The percentages of the different genera of fungi identified in the present study suggest the need of using protective masks when workers are inside the poultry house. Finally, a potential risk of impairing bird performance exists in the case of birds housed under high floor density.

\section{REFERENCES}

Brasil. Resolução 176, de 24 de outubro de 2000. Diário Oficial da União, Brasília, DF, 25 out. 2000.

Cervantes $\mathrm{H}$. Evaluación y manejo de los problemas respiratorios en los pollos de engorde. Avicultura Profesional 1995; 2:76-84.

Daly P, Kavanagh K. Pulmonary aspergillosis: clinical presentation, diagnosis and therapy. Brazilian Journal Biomedical Science 2001; 58:197.

El-Gharib I, Eldin, AMWK, Bastami MA; Wahba S, Safwat, EEA, Hatem, E. Incidence of isolation of microorganisms leading to embryonic mortalities and reducing hatchability of duck eggs. Veterinary Medical Journal Giza 1993; 3:63-65.

Fraser CM, editor. Aspergilose In: Fraser CM, editor. Manual merck de veterinária. 6.ed. São Paulo:Roca; 1991. p.1439-1440.

Fraser RS. Pulmonary aspergillosis: pathologic and pathogenetic features. Pathology. Annual 1993; 28:231.

Kristensen $\mathrm{HH}$, Wathes $\mathrm{CM}$. Ammonia and poultry welfare: a review. World's Poultry Science Journal 2000; 56(3):235-245.

Leeson S, Diaz GJ, Summers JD. Poultry metabolic disorders and mycotoxins. Guelph: University Books; 1995.

Perkins S, Morrison WD. The effects of the quality of the environment in poultry buildings on the productivity of poultry and safety of 
Gigli ACS, Baracho MS, Nääs IA,

humans. Guelph, Ontario:University of Guelph; 1991.

Quilles AY, Hevia ML. Medidas de bioseguridad en las granjas avícolas. Departamento de Producción Animal, Facultad de Veterinaria, Universidad de Murcia. Campus de Espinardo. 30100Murcia; 2003.

Raper KB, Fennell DI. The genus Aspergillus. Baltimore: The Willians \& Willians Company; 1965.

Richard JL. Aspergillosis. In: Calnek BW. Diseases of poultry. lowa: lowa State University Press; 1977. p. 351-360.

Silveira VD. Lições de micologia. 3. ed. Rio de Janeiro: Editora José Olympio; 1968

Stoloff L. Aflatoxin as a cause of primary liver cell cancer in the United States: a probability study. Nutrition and Cancer 1983; 5:165-186.

Strom G, Blomquist G. Airborne spores from Mouldy citrus fruit: a potential occupational health hazard. Annals of Occupational Hygiene 1986; 30:455-460.

Todaro F. Aerospore fungine come fattori di rischio per gli operai di opifici industriali agrumari. Nuovi Annali d'Igiene e Microbiologia 1978; 29:443-458.

Vilar EA, Vilela SMO, Saukas TN. Infecção de embriões de codornas (Coturnix coturnix japonica). por Aspergillus sp. e Penicillium sp. In: Conferência APINCO de Ciência e Tecnologia Avícolas 1995; Londrina, BRA. Campinas, SP:FACTA; 1995. p. 143-144.

Wathes CM. Aerial emissions from poultry production. World's Poultry Science Journal 1998; 54(3):241-251. 